\title{
A Comparative Histological and Immunohistochemical Study of the Effect of Oxandrolone and Whey Protein on Disuse Induced Muscle Atrophy in old aged male rats
}

\section{Original Article}

\author{
Samiha Aly Mortada, Rahma Kamaleldin Abou Elnour, Amal Elham Fares, \\ Dina Hisham
}

Department of Histology, Faculty of Medicine, Cairo University

\begin{abstract}
Background: Periods of immobilization are often associated with pathologies and/or aging. These periods of disuse muscle atrophy could worsen the pathology or elderly frailty. Exercise, the best way to recover muscle mass, is not always applicable. Aim of Work: This study aimed to compare the therapeutic effect of oxandrolone versus whey protein on disuse induced muscle atrophy in old aged male rats with low testosterone level and mobility limitation.

Materials and Methods: Twenty four aged male albino rats were included: 6 rats as control (group I). Eighteen rats were subjected to hind limb suspension (HLS) for 2 weeks then were divided into: 6 rats as group II (disuse atrophy) and 12 rats as group III (treated group) which was equally subdivided into: group IIIa (oxandrolone treated) and IIIb (whey protein treated) where oxandrolone $1.23 \mathrm{mg} / \mathrm{kg}$ and whey protein $9.25 \mathrm{gm} / \mathrm{kg}$ were given orally daily for 4 weeks. Rats were sacrificed after 6 weeks. Gastrocnemius muscle weight and total protein content were measured. Muscle specimens were stained with Hematoxylin and Eosin, PAS and immunohistochemical staining for Myogenin. Morphometric measurements of type I and type II fibers number and cross sectional area (CSA), number of myogenin positive cells (differentiated satellite cells) were taken and statistically analyzed.

Results: Group II showed atrophic angulated muscle fibers and significant increase in type II fibers compared to the control. Subgroup IIIa showed muscle fibers with large diameter. Many rounded vesicular nuclei were observed among muscle fibers. A significant increase in type I fibers and number of myogenin positive cells as compared to the control and subgroup IIIb. Conclusion: Oxandrolone and whey protein treated subgroups showed improved muscle mass, CSA, total protein content, histological architecture of muscle fibers and increase of satellite cells number. However, oxandrolone showed better therapeutic potential in ameliorating disuse muscle atrophy.
\end{abstract}

Received: 14 January 2019, Accepted: 17 January 2019

Key Words: Muscle atrophy, myogenin, HLS, oxandrolone, whey protein.

Corresponding Author: Dina Hisham, MD, Department of Histology, Faculty of Medicine, Cairo University, Cairo, Egypt, Tel.: +20 1009950216, E-mail: dr.dinahisham@yahoo.com

ISSN: 1110-0559, Vol. 42, No. 2

\section{INTRODUCTION}

Muscle atrophy occurs in the presence of inactivity, sarcopenia and various neuromuscular diseases leading to a marked decrease in physical activity and the inevitable progression of muscle wasting ${ }^{[1]}$.

Skeletal muscle possesses a highly plastic potential to cope with the demands of various environmental conditions. It is composed of a variety of proteins and is regulated by the balance between protein synthesis and degradation. However, marked increase in protein degradation and decrease in protein synthesis will result in muscle atrophy ${ }^{[1]}$.

There has been increasing interest in the development of effective agents that can be safely used to promote anabolism in the clinical setting for patients with chronic wasting conditions as well as in the prevention and treatment of frailty associated with loss of muscle tissue in aging (sarcopenia) ${ }^{[2]}$.

Satellite cells have been shown to possess a critical role in skeletal muscle regeneration, during which satellite cells are activated, proliferate and differentiate to support regeneration and new myofiber formation ${ }^{[3]}$.

Apart from often strenuous and high intensity exercise prescriptions that may not always be well tolerated especially in old age, alternative protocols could be a reasonable and feasible approach for reduction of muscle wasting in prolonged inactivity in bed rest, critical illness or nerve damage. The emphasis is on the therapies that can 
increase muscle mass and improve functional outcomes that will ultimately lead to improvement in the quality of life for affected patients ${ }^{[4]}$.

Endogenous testosterone production gradually decreases with advancing age in men. Anabolic therapies are currently widely used to promote retention and gain of muscle mass and strength in hypogonadal old men ${ }^{[5]}$. Oxandrolone is the only anabolic androgenic steroid that is FDA approved for treatment of muscle wasting. It increases protein synthesis and accelerates activation of satellite cells ${ }^{[6]}$.

Essential amino acids (EAA), especially branched chain amino acids (BCAA), have a particular role in the regulation of muscle protein synthesis. Many studies have demonstrated that BCAA stimulate muscle protein synthesis, facilitate the initiation of mRNA translation and suppress protein degradation. Whey protein is a rich source of BCAA and is thought to have beneficial effects on skeletal muscle turnover ${ }^{[7]}$.

\section{MATERIAL AND METHODS}

\section{A-Material}

\section{(I) Drugs used}

1. Anesthesia: a mixture of Ketamine $(60 \mathrm{mg} / \mathrm{kg})$ (Pfizer Pharmaceuticals, Egypt) and Xylazine (10 mg/kg) (Adura Pharmaceuticals, Egypt) was administered intraperitonealy ${ }^{[8]}$.

2. Oxandrolone: (trade name Anavar) in the form of tablets $10 \mathrm{mg}$ each (Meditech Human Pharmaceuticals, Ingoldheim, Germany). Each tablet was crushed and dissolved in $5 \mathrm{ml}$ sesame oil. Oxandrolone human dose $0.2 \mathrm{mg} / \mathrm{kg}^{[2]}$ was converted to rat dose $1.23 \mathrm{mg} / \mathrm{kg}^{[9]}$.

3. Whey protein: $100 \%$ pure whey protein isolate in the form of powder (OLIMP sport nutrition, OLIMP LABORATORIES, EU) was used. A serving of $25 \mathrm{~g}$ was dissolved in $20 \mathrm{ml}$ water. Whey protein human dose $1.5 \mathrm{gm} / \mathrm{kg}^{[10]}$ was converted to rat dose $9.25 \mathrm{gm} / \mathrm{kg}^{[9]}$.

\section{(II) Animals}

Twenty four aged male albino rats 18-20 months were used in this study, their weights ranging from 250-350 gm each with serum total testosterone level not exceeding $3.18 \pm 0.14 \mathrm{ng} / \mathrm{ml}^{[11]}$. The study was conducted at the Animal House of Kasr-Al Aini School of Medicine, according to the guidelines for the care and use of laboratory animals after the approval of the ethical committee. Each subgroup was housed separately in standard stainless-steel cages and each animal in group II was housed separately in smaller stainless-steel cages under standard environmental conditions with free access to a standard chow and water (ad libitum).

\section{Experimental Design}

Animals were randomly divided into the following 3 groups:

- Group I (Control Group): ( $\mathrm{n}=6)$

Rats received anesthesia in the form of a mixture of ketamine $(60 \mathrm{mg} / \mathrm{kg})$ and xylazine $(10 \mathrm{mg} / \mathrm{kg})$ by intra peritoneal injection ${ }^{[8]}$

Then rats were further subdivided into the following subgroups:

- Subgroup Ia: $(\mathrm{n}=2)$

Rats were sacrificed after 2 weeks.

- Subgroup Ib: $(n=2)$

After 2 weeks, rats received $0.3 \mathrm{ml}$ sesame oil [the solvent of oxandrolone] daily by oral route for 4 weeks. Rats were sacrificed after 6 weeks.

- Subgroup Ic: $(\mathrm{n}=2)$

Rats were sacrificed after 6 weeks.

- Group II (Disuse Atrophy Group): ( $\mathrm{n}=6)$

Hind Limb Suspension (HLS) ${ }^{[12]}$ was done to induce atrophy in right gastrocnemius muscle and rats were sacrificed after 2 weeks to confirm atrophy ${ }^{[13]}$.

- Group III (treated Group): ( $\mathrm{n}=12)$

Rats were further equally subdivided into the following subgroups:

Rats were subjected to HLS as in group II, left untreated for 2 weeks then received oxandrolone in subgroup IIIa $(n=6)$ and whey protein in subgroup IIIb $(n=6)$ orally daily through gastric gavage for 4 weeks then rats were sacrificed after 6 weeks from HLS.

\section{B-Methods}

\section{I- Disuse muscle atrophy}

Animals were anesthetized then were subjected to Hind limb suspension (HLS). Stainless steel multifilament electrode insulated needle was inserted along the proximal part of the tail and then attached to the cover of the cage to provide free movement of the rat around the cage. The forelimbs remained in contact with the cage floor, which allowed the animals to move and obtain food and water freely. The exposed tail was monitored to ensure that it remained pink, indicating that the blood flow to the tail was not compromised. Each animal was suspended in a separate cage to ensure the competence of the procedure and prevent rats from cutting off the tails of each other from the cover of the cage. After reloading rats were put in small cages to limit their mobility ${ }^{[12]}$. 


\section{II-Biochemical Investigations: Serum total Testosterone}

Blood samples were collected from the tail veins of rats before the start of the experiment and before time of sacrifaction in induced atrophy group and oxandrolone treated subgroup ${ }^{[14]}$. Rats with serum total testosterone level above $3.18 \pm 0.14 \mathrm{ng} / \mathrm{ml}$ at the start of the experiment were excluded. Blood samples were also collected from young adult (8-10 months) rats and serum total testosterone was measured $(6.07 \pm 1.23 \mathrm{ng} / \mathrm{ml})$.

\section{III-Total Muscle Protein Content}

Total muscle protein content was measured as a test for estimating muscle atrophy in addition to increased protein synthesis after treatment. Total muscle proteins were extracted by treating 100-200 mg of gastrocnemius muscle tissue with HCL and PBS then muscle homogenate was centrifuged at $12000 \mathrm{rpm}$. The supernatant was used for detection of total protein content using a Bio-Rad protein assay (Bio-Rad, Hercules, CA, USA) ${ }^{[15]}$.

\section{IV-Light Microscopic Examination}

Mid-belly portions of right gastrocnemius muscle specimens were obtained and paraffin sections were subjected to the following stains:

\section{1-Histological Staining}

a-Hematoxylin \& Eosin (H\&E) stain ${ }^{[16]}$ for histological evaluation.

b-Periodic Acid Schiff (PAS) stain ${ }^{[17]}$ was used to differentiate between types of muscle fibers

- Type I (little glycogen content) appear lightly stained

- Type II (abundant glycogen content) appear darkly stained

2- Immunohistochemical staining: using the avidinbiotin peroxidase complex technique ${ }^{[18]}$, for detection of: Myogenin immunopositive cells. Myogenin is a musclespecific basic-helix-loop-helix (bHLH) transcription factor involved in the coordination of skeletal muscle development or myogenesis and repair. Myogenin is a member of the MyoD family of transcription factors ${ }^{[19]}$.

\section{VI- Morphometric Study}

Data were obtained using "Leica Qwin 500 C" image analyzer computer system Ltd. (Cambridge, England). For each group, five slides of five different specimens were examined. From each slide, ten non-overlapping fields were measured in a standard measuring frame. The following parameters were measured:

1. The mean number of type I (light) and type II (dark) fibers in PAS stained sections (x100 magnification).

2. The mean CSA of type I (light) and type II (dark) fibers of gastrocnemius muscle in PAS stained sections of the studied groups (x100 magnification).
3. The mean number of immunopostive myogenin stained cells in myogenin stained sections in different fields (x200 magnification).

\section{VII- Statistical Analysis}

The measurements obtained were analyzed using SPSS software version 16 (SPSS, Chicago, IL). Comparison between different groups was made using analysis of variance (ANOVA) followed by post hoc Tukey test. The results were expressed as means \pm standard deviation (SD). The differences were considered statistically significant when " $p$ value" was $<0.05^{[20]}$.

\section{RESULTS}

No mortality was recorded in the present study.

\section{(I) Biochemical Investigations}

The mean serum total Testosterone level in selected studied groups (Histogram 1):

The mean serum total testosterone level of aged rat (1820 months) was $3.18 \pm 0.14 \mathrm{ng} / \mathrm{ml}$. A significant increase in the mean serum total testosterone was reported in subgroup IIIa (oxandrolone treated) $(4.01 \pm 1.27 \mathrm{ng} / \mathrm{ml})$ when compared to group II (disuse) $(3.22 \pm 0.55 \mathrm{ng} / \mathrm{ml})$. Among all oxandrolone treated rats, the mean serum testosterone level never went out of the normal level of young adult (810 months) rat $(6.07 \pm 1.23 \mathrm{ng} / \mathrm{ml})$ which was also measured in this study.

(II) The mean total muscle protein content of right gastrocnemius muscle (Histogram 2):

A significant decrease in the total protein content of gastrocnemius muscle was reported in group II (disuse) $(45.1 \pm 1.23)$ as compared to the control group (85.9 \pm 0.71 ). Subgroup IIIa (oxandrolone treated) (74.8 \pm 1.73$)$ showed a significant increase in the total protein content as compared to group II (disuse) and subgroup IIIb (whey protein treated) (71.4 \pm 2.79 ). Meanwhile, subgroup IIIb showed a significant increase in this value as compared to group II.

\section{(III) Histological Results}

\section{(a) Hematoxylin and Eosin Stained Sections (Fig.1)}

Light microscopic examination of transverse sections of the control group I showed normal organization of skeletal muscle bundles. Each bundle consisted of a group of muscle fibers surrounded by C.T. perimysium. Muscle fibers appeared polyhedral with peripherally located oval nuclei and acidophilic sarcoplasm separated by narrow C.T. endomysium. Group II (disuse atrophy) showed myofiber size and shape variation, rounded atrophic fibers and some angulated atrophic fibers with small diameter. Apparent widening of spaces inbetween muscle fibers was noted. Some myofibers showed crowded nuclei (Nuclear clump). Dilated blood vessels were seen within the muscle bundles. 
Subgroup IIIa (oxandrolone treated) showed muscle fibers with apparent large diameter and multiple peripheral nuclei, some nuclei appeared rounded and vesicular. Narrow C.T. endomysium was observed between muscle fibers as well as some blood vessels. Subgroup IIIb (whey protein treated) showed muscle fibers with apparent large diameter and narrow C.T. endomysium inbetween. Muscle bundles were surrounded by wide C.T. perimysium. Muscle fibers exhibited large number of peripheral nuclei while others showed centrally located ones. Elongated multinucleated fibers (myotubes) were present.

\section{(b) Periodic Acid Schiff's Stained Sections (Fig.2)}

Transverse sections of control group I showed mild PAS positive reaction in some fibers (type I muscle fibers) and dense PAS positive reaction in others (type II muscle fibers). Group II (disuse atrophy) showed dense PAS positive reaction in most fibers (type II) and mild PAS positive reaction in some fibers (type I). Subgroup IIIa (oxandrolone treated) showed mild PAS positive reaction (type I) in most fibers while few showed dense PAS positive reaction (type II). Subgroup IIIb (whey protein treated) showed dense PAS positive reaction in some fibers (type II) while others showed mild PAS positive reaction (type I).

\section{(IV) Immunostaining with Myogenin (Fig.3)}

Transverse sections of control group I showed few immunopositive nuclei close to sarcolemma of muscle fibers (differentiated satellite cells). Group II (disuse atrophy) showed negative immune reaction for myogenin. Subgroup IIIa (oxandrolone treated) showed multiple immunopositive nuclei close to sarcolemma of muscle fibers. While subgroup IIIb (whey protein treated) showed some immunopositive nuclei close to sarcolemma of muscle fibers.

\section{(V) Quantitative Morphometric Results}

(a) Mean number of light (type I) and dark (type II) fibers in PAS stained sections (Histogram 3)

The mean numberof light (type I) fibers of the control group was (77.8 \pm 2.35$)$. This value showed a significant decrease in disuse atrophy group when compared to the control group, being (14.7 \pm 2.83$)$. There was a significant increase in subgroup IIIa (oxandrolone treated) $(107.2 \pm 1.55)$ when compared to the control group, the disuse group (group II) and also the whey protein treated subgroup (subgroup IIIb) (75.4 \pm 1.07$)$. While the mean number of dark (type II) fibers of the the control group (I) was (72.2 \pm 2.35$)$. A significant increase in this value was reported in disuse atrophy group being (135.3 \pm 2.83 ), as compared to the control group. Value reported for subgroup IIIa (oxandrolone treated) $(42.8 \pm 1.55)$ represented a significant decrease when compared to the control group, the disuse group (group II) and also the whey protein treated subgroup (subgroup IIIb) (74.6 \pm 1.07$)$.

\section{(b) Mean CSA of light (type I) and dark (type II) fibers of in PAS stained sections (Histogram 4)}

The mean CSA of light (type I) fibers of the control group was $(157.3 \pm 10.68)$. A significant decrease in this value was reported in group (II) being $(90.3 \pm 15.02)$, as compared to the control group. A significant increase in the mean area of light (type I) fibers was noted in subgroup IIIa, being (197.7 \pm 51.65$)$, as compared to the control group, group II and subgroup IIIb (145.7 \pm 12.68$)$. While the mean CSA of dark (type II) fibers of the control group was $(156.7 \pm 10.69)$. A significant decrease in this value was reported in group (II) being $(88.1 \pm 14.15)$, as compared to the control group. A significant increase in the mean area of dark (type II) fibers was noted in subgroup IIIa $(157.5 \pm 15.77)$ as compared to group II. However, this value was not statistically significant when compared to the control group.

\section{(c) Mean number of immunopostive nuclei (differentiated satellite cells) in Myogenin stained sections (Histogram 5)}

The mean number of immunopositive nuclei of the control group was $(1.2 \pm 0.79)$. The value reported for disuse (group II) was non-significant when compared to the control, being $(0.5 \pm 0.03)$. The mean number of immunopositive nuclei of subgroup IIIa (17.2 \pm 1.23$)$ showed a significant increase as compared to the control group, group II and subgroup IIIb $(6.9 \pm 0.88)$. However, subgroup IIIb represented a significant increase in this value when compared to the control group and the disuse group. 


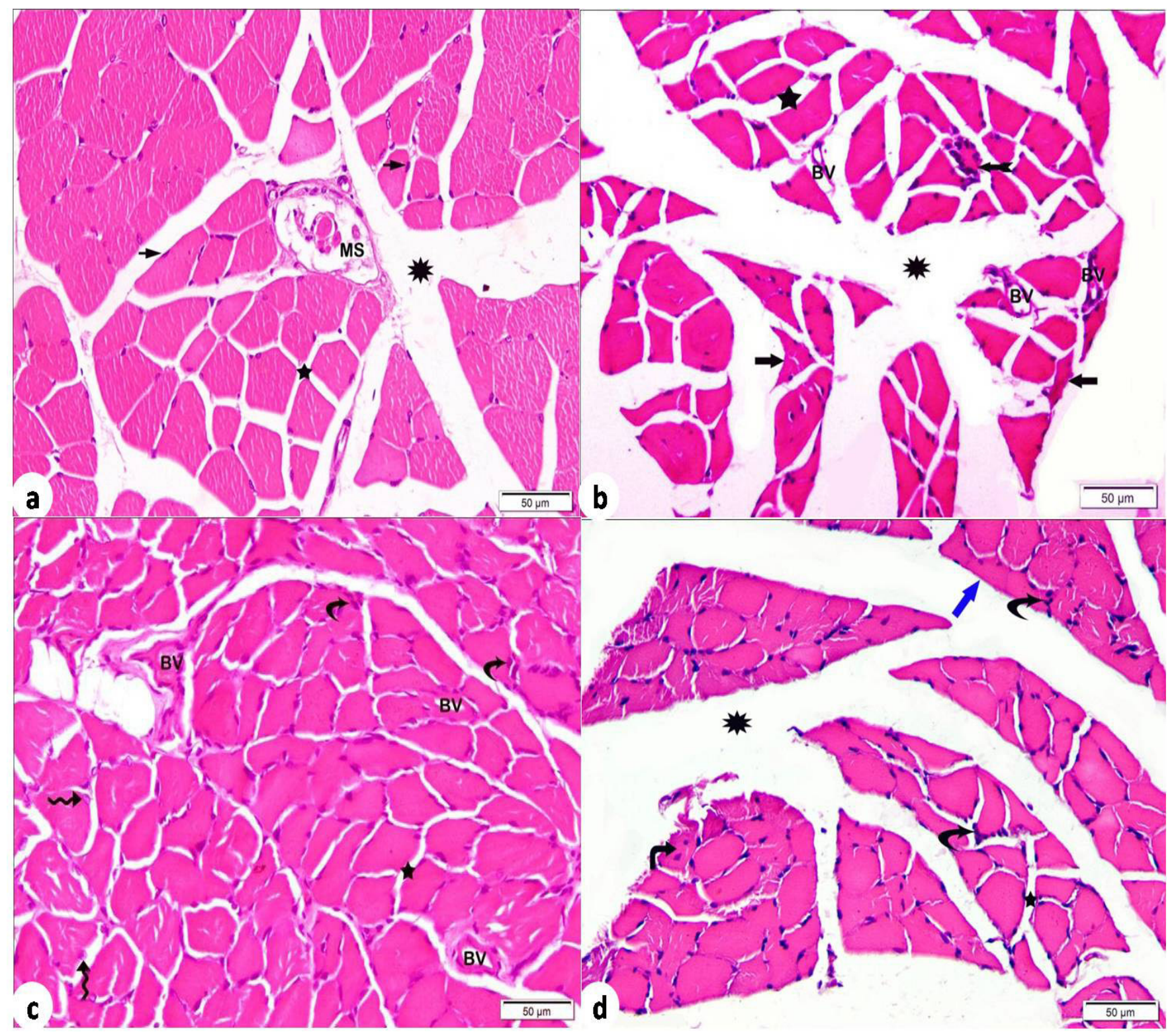

Fig. 1: photomicrographs of transverse section from gastrocnemius muscle of:

- A (control group): showing polyhedral muscle fibers with acidophilic sarcoplasm and multiple peripheral oval nuclei (arrows) separated by narrow C.T. endomysium (star). A wide C.T. perimysium (asterix) is present between skeletal muscle bundles. A muscle spindle (MS) is seen between the skeletal muscle fibers.

- B (disuse group II): showing angulated muscle fibers of various shape and size (arrows) separated by wide C.T. endomysium (star). Some dilated blood vessels (BV) are seen within the muscle bundles. Note the presence of a myofiber with crowded nuclei (nuclear clump) (bifid arrow) and wide perimysium (asterix).

- $\mathrm{C}$ (disuse subgroup treated by oxandrolone IIIa): showing muscle fibers separated by narrow C.T. endomysium (star). Muscle fibers show multiple peripheral nuclei (curved arrows). Note the presence of some rounded and vesicular nuclei close to sarcolemma (wavy arrows). Some dilated blood vessels (BV) are seen in the surrounding C.T.

- D (disuse subgroup treated by whey protein IIIb): showing muscle fibers with apparent large number of nuclei (curved arrows) separated by narrow C.T. endomysium (star). Some muscle fibers have central nuclei (right angle arrow). Muscle bundles are separated by wide C.T. perimysium (asterix). Note the presence of an elongated multinucleated fiber (myotube) (blue arrow).

(Hx and E x200) 


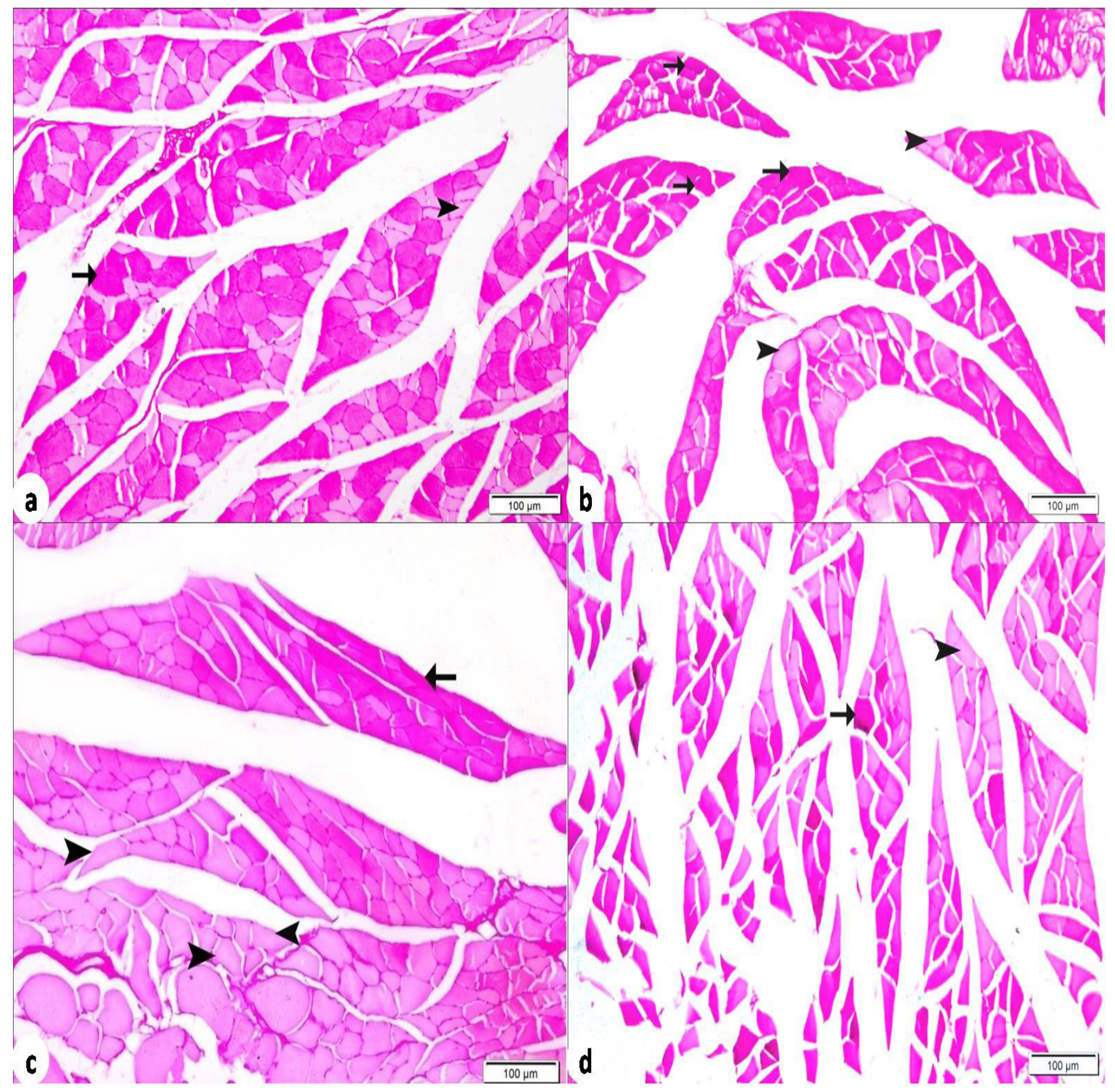

Fig. 2: A photomicrograph of transverse section of gastrocnemius muscle of:

- A (control group): showing dense PAS positive reaction in some fibers (type II) (arrow) and mild PAS positive reaction in others (type I) (arrowhead).

- B (disuse group II): showing dense PAS positive reaction in most fibers (type II) (arrows). Mild PAS positive reaction is also noted in some muscle fibers (type I) (arrowheads).

- $\mathrm{C}$ (disuse group treated by oxandrolone IIIa): showing mild PAS positive reaction (type I) (arrowheads) in most fibers while few show dense PAS positive reaction (type II) (arrow).

- D (disuse group treated by whey protein IIIb): showing apparent dense PAS positive reaction in some fibers (type II) (arrow) while others show mild PAS positive reaction (type I) (arrowhead). 


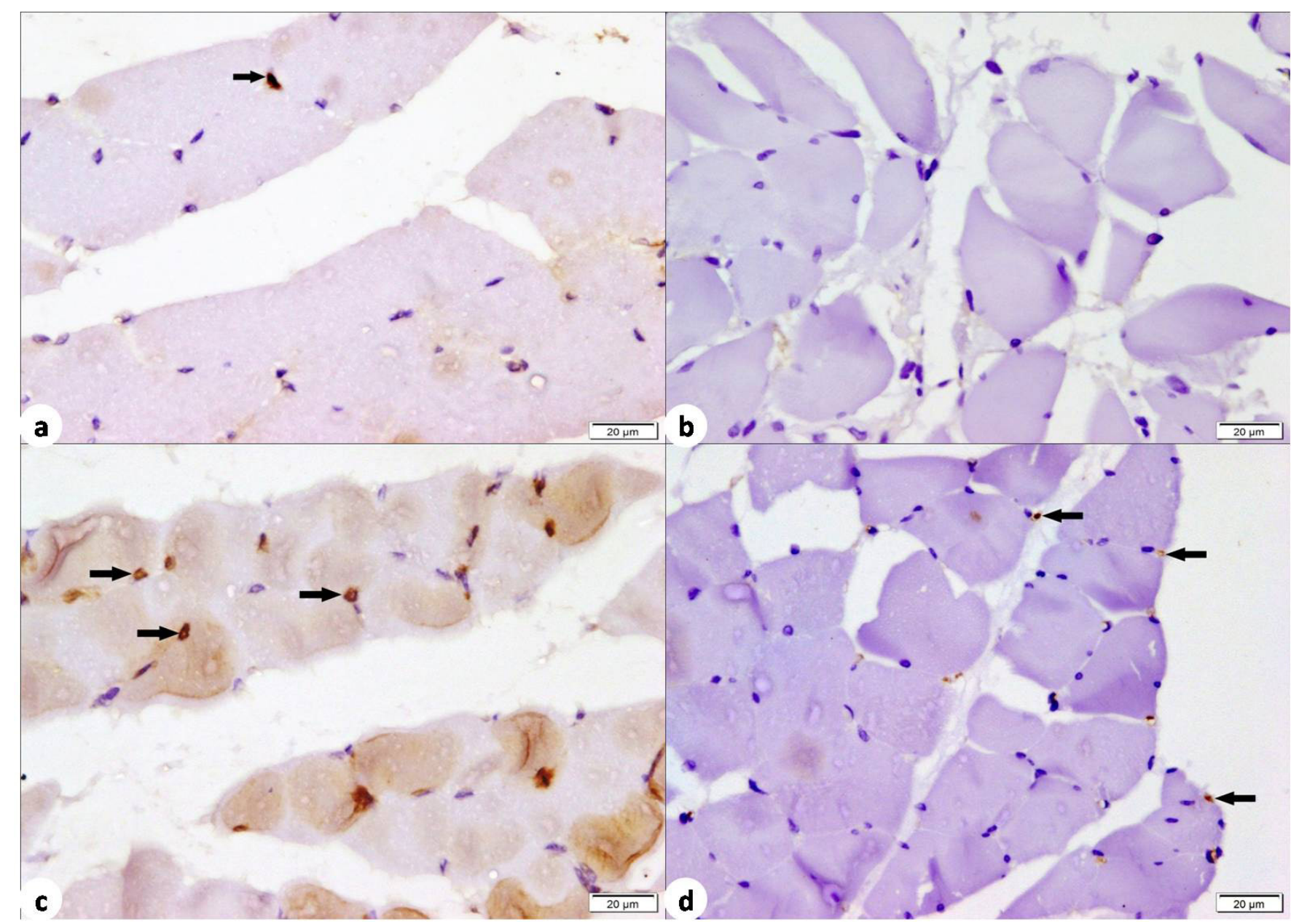

Fig. 3: A photomicrograph of transverse section of gastrocnemius muscle of:

- A (control group): showing an immunopositive nucleus close to sarcolemma of muscle fibers (arrow).

- B (disuse group II): showing negative immune reaction.

- C (disuse group treated by oxandrolone IIIa): showing multiple immunopositive nuclei close to sarcolemma of muscle fibers (arrows).

- D (disuse group treated by whey protein IIIb): showing some immunopositive nuclei close to sarcolemma of muscle fibers (arrows).

(Myogenin immunostaining x400)

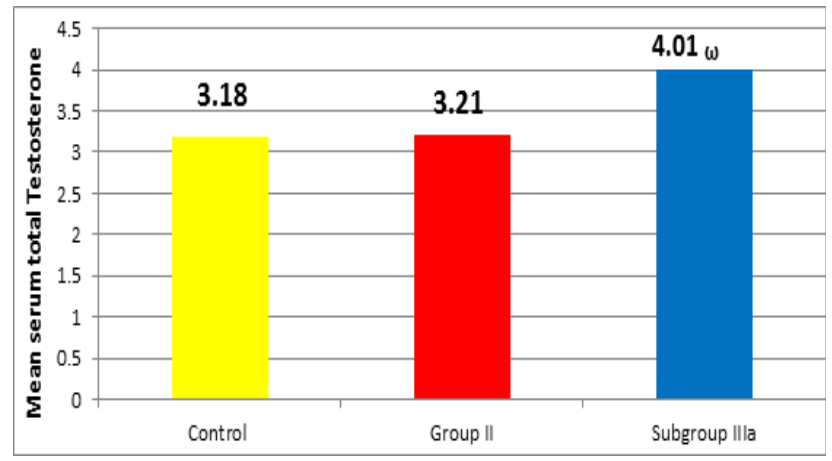

Histogram 1: Mean serum total Testosterone level in selected studied groups

$\omega$ Significantly different from the value of group II at $P<0.05$

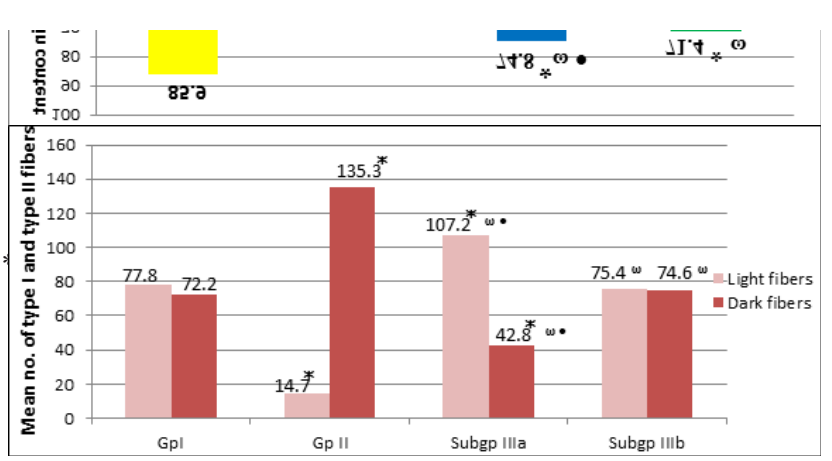

Histogram 3: Mean number of light (type I) and dark (type II) fibers in PAS stained sections

* Significantly different from the value of the control group at $P<0.05$ 
$\omega$ Significantly different from the value of group II at $P<0.05$

- Significantly different from the value of subgroup IIIb at $P<0.05$

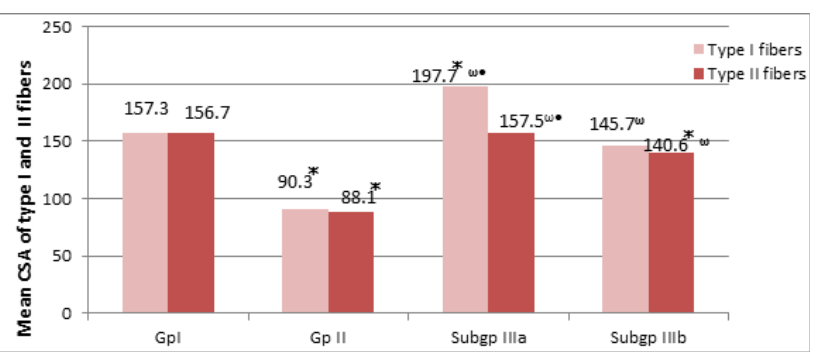

Histogram 4: Mean CSA of light (type I) and dark (type II) fibers of in PAS stained sections

*Significantly different from the value of the control group at $P<0.05$

$\omega$ Significantly different from the value of group II at $P<0.05$

- Significantly different from the value of subgroup IIIb at $P<0.05$

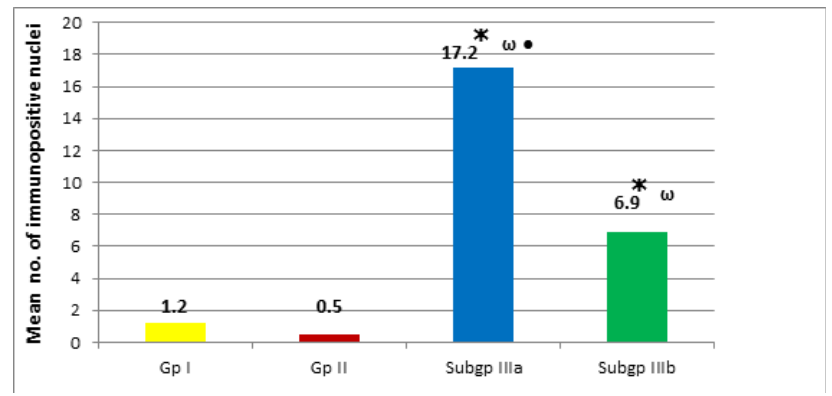

Histogram 5: Mean number of immunopostive nuclei (differentiated satellite cells)in Myogenin stained sections

*Significantly different from the value of the control group at $P<0.05$

$\omega$ Significantly different from the value of group II at $P<0.05$

- Significantly different from the value of subgroup IIIb at $P<0.05$

\section{DISCUSSION}

Various approaches such as resistance training, nutritional supplementation, hormonal and pharmacological treatment have been attempted to inhibit muscle atrophy particularly in sarcopenia ${ }^{[1]}$. Muscle size is dependent on the number and volume of muscle fibers, which is directly related to satellite cells. These quiescent and undifferentiated cells are activated from the quiescent state upon appropriate stimulatory signals and undergo active proliferation and myogenic differentiation ${ }^{[21]}$.

Hind limb suspension, the most commonly used animal model to experimentally induce muscle atrophy in rats ${ }^{[2]}$ was used in the present study. Rats were put in small cages after unloading to limit their mobility. Gastrocnemius musle was the muscle of choice as it provides a reasonable amount of tissue to be examined, contains both fast and slow twitch muscle fibers and it's one of the antigravity muscles $^{[22]}$.

The FDA approved drug, oxandrolone was used In the present study, as it is an androgenic steroid with high anabolic to androgenic potency, less expensive and can be administered orally as well as less hepatotoxic compared to other androgens ${ }^{[23]}$. Moreover, androgen administration can increase satellite cell number in animals and humans in a dose dependent manner ${ }^{[24]}$.

Healthy older men provide a unique model to assess the mechanism by which testosterone promotes muscle anabolism by increasing testosterone while still maintaining serum values within the normal range. So, in the present study, all rats entered the study with average concentrations of circulating total testosterone in the lower half of normal range $(3.18 \pm 0.14 \mathrm{ng} / \mathrm{ml})$ and never went out, in all groups treated with oxandrolone ${ }^{[25]}$.

Whey protein was used in the present study as it is a rich source of BCAA and is thought to have beneficial effects on skeletal muscle turnover. Ingestion of whey protein strongly stimulates muscle protein synthesis in a dose-dependent manner as they facilitate the initiation of mRNA translation ${ }^{[7]}$. Moreover, delivery and uptake of glucose and essential amino acids may also influence satellite cell activity ${ }^{[26]}$.

The total protein content, as an outstanding measure of atrophy and protein synthesis, was measured in all groups. The values reported for the disuse atrophy group were significantly less than that of control group which indicates protein degradation. Oxandrolone treated subgroup was significantly higher than disuse atrophy group and whey protein treated subgroup. This might be due to the anabolic effect of oxandrolone and its ability to increase protein synthesis. Camerino et al. $(2015)^{[15]}$ reported that hindlimb unloading induced a significant drop of protein content of muscle with respect to control, however total muscle protein content was preserved by nandrolone treatment. Also whey protein treated subgroup showed a significant increase in the total protein content of gastrocnemius muscle as compared to disuse atrophy group but was significantly less than oxandrolone treated one. This indicates that whey protein increased the protein synthesis or has anticatabolic effects ${ }^{[4]}$.

Histological examination of $\mathrm{H} \& \mathrm{E}$ stained sections of disuse atrophy group showed marked myofiber size variation. Some atrophic fibers appeared rounded while others were angulated. Similar results were reported by Bodine (2013) ${ }^{[27]}$. Crowded nuclei (Nuclear clump) were also noted in this group. This could be explained by that, in atrophy, some myofibers become depleted of myofibrillar apparati and might become severely atrophic to the point that there was only a nuclear clump left ${ }^{[28]}$.

Muscle fibers with large diameter, as confirmed by quantitative morphometric results for CSA in oxandrolone treated subgroup, was found in the present study. This anabolic effect was likely mediated by binding to the androgen receptor (AR) that allowed the activation of specific DNA nucleotide sequences in the nucleus which influenced the transcriptional activity of specific proanabolic genes ${ }^{[15]}$. Large number of rounded vesicular nuclei close to sarcolemma, confirmed by myogenin 
immunostaining to be activated satellite cells nuclei, were noted. Some of these nuclei appeared in the C.T. endomysium between muscle fibers which indicated that it is possible that migrating satellite cells also differentiate and help form new fibers rather than fuse with parent fiber. Androgen administration also increases satellite cell number and androgen receptor levels in animals and humans in a dose-dependent manner ${ }^{[24]}$.

Histological examination of H\&E stained sections of whey protein treated subgroup showed muscle fibers with large diameter, as confirmed by quantitative morphometric results for CSA. Similar findings were reported by Bunn $(2012)^{[29]}$. Some muscle fibers with central nuclei were also found indicating regenerating muscle fibers ${ }^{[30]}$. In vitro satellite cell (SC) proliferation is increased with administration of essential amino acids (EAAs), possibly mediated through an increased activation of the mammalian target of rapamycin (mTOR) kinase complex and subsequent increased mRNA translation ${ }^{[31]}$.

Elongated multinucleated muscle fibers (myotubes) were also noted in subgroup IIIb. This might be an attempt of myotube regeneration stimulated by whey protein. During regeneration, several myoblasts fuse to form myotubes which may serve as a scaffold and eventually increase in size and nuclei number by fusing with additional myoblasts eventually forming a multinucleated contractile muscle fiber ${ }^{[32]}$.

PAS stained sections of disuse atrophy group showed a significant increase of darkly stained type II muscle fibers as compared to the control. Similar findings were reported by Brooks and Myburgh (2014) ${ }^{[33]}$.This might be due to reduced capacity for fat oxidation in skeletal muscle in cases of disuse ${ }^{[34]}$. A significant decrease in the mean CSA of both type I and type II muscle fibers, with slightly greater loss of CSA of type II fibers, in disuse atrophy group as compared to the control was noted. The decline in type II muscle fiber size is reported in some studies to be accompanied by an age-related reduction in type II muscle fiber satellite cell content and function ${ }^{[35]}$.

The significant increase in the number and CSA of type I in oxandrolone treated subgroup when compared to the disuse atrophy group was also reported by Ustunel et al. $(2003)^{[36]}$ who stated that it might be due to an increase in bifurcation of myofibrils, an increase in the number and diameter of units resembling $\mathrm{T}$ tubules, an increase in pinocytic vesicles and an increase in ribosomal content of type I fibers. This might also be due to different number of androgen receptors in different fiber types.

Whey protein treated subgroup showed more type I muscle fibers than type II with a significant increase of CSA of both types as compared to disuse atrophy group. This goes with Cribb et al. (2007) ${ }^{[37]}$ who found no changes in fiber type proportions in groups treated by whey protein across time and reported that an increase in contractile protein content, induced by whey protein, is thought to be an important stimulus that results in an increase in muscle fiber CSA across all fiber types. Comparing morphometric results, oxandrolone treated subgroup in the present work showed a significant increase in the number and CSA of type I fibers than whey protein treated subgroup.

Anti-myogenin immunostaining of the nuclei of muscle fibers in the present study was negative in disuse atrophy group which was also reported in human studies of 14 days immobilization ${ }^{[38]}$. A significant increase in the number of immunopositive nuclei (differentiated satellite cells) was observed in the subgroup treated by oxandrolone as compared to the control and disuse atrophy group. Testosterone induced increase in muscle mass is associated with a proportionate increase in the number of satellite cells and myonuclei ${ }^{[39]}$. In whey protein treated subgroup, the number of immunopositive nuclei showed a significant increase when compared to the control group and the disuse atrophy group. Farup et al. (2014) ${ }^{[3]}$ reported similar results and mentioned that, whey protein accelerated the expansion of the satellite cell pool, when compared with placebo supplement. However, the number of immunopositive nuclei of whey protein treated subgroup showed significant decrease when compared to the oxandrolone treated subgroup, suggesting greater efficacy of oxandrolone versus whey protein in activation of satellite cells.

\section{CONCLUSION}

Oxandrolone proved to have better therapeutic potential than whey protein in ameliorating disuse muscle atrophy in old aged male rats with low testosterone level and mobility limitation by stimulating and enhancing satellite cells differentiation.

\section{CONFLICTS OF INTEREST}

The authors have no conflicts of interest to declare.

\section{REFERENCES}

1. Asami Y, Aizawa M, Kinoshita M, Ishikawa $\mathrm{J}$ and Sakuma K: Resveratrol attenuates denervation-induced muscle atrophy due to the blockade of atrogin-1 and p62 accumulation. International Journal of Medical Sciences. (2018) 15(6): 628-637.

2. Orr $\mathrm{R}$ and Singh $\mathrm{M}$ : The anabolic androgenic steroid oxandrolone in the treatment of wasting and catabolic disorders: review of efficacy and safety. Drugs. (2004)64(7):725-750.

3. Farup J, Rahbek S, Knudsen I, De Paoli F, Mackey A, Vissing K: Whey protein supplementation accelerates satellite cell proliferation during recovery from eccentric exercise. Amino Acids. (2014)14(3): 1-15.

4. Blottner D, Bosutti A, Degens H, Schiffl G, Gutsmann M, Buehlmeier J, Rittweger J, Ganse $\mathrm{B}$, Heer $\mathrm{M}$ and Salanova $\mathrm{M}$ : Whey protein 
plus bicarbonate supplement has little effects on structural atrophy and proteolysis marker immunopatterns in skeletal muscle disuse during 21 days of bed rest. J Musculoskelet Neuronal Interact.(2014) 14(4):432-444.

5. Dillon E, Durham W, Urban R and SheffieldMoore $\mathrm{M}$ : Hormone treatment and muscle anabolism during aging: Androgens. ClinNutr. (2010) 29(6):697-700.

6. 6. Cox C: Sarcopenia and Muscle metabolism. CRC press. (2016) 3:258-260.

7. Kobayashi Y, Somoto Y, Mitsuyama E, Tanaka A, Yuda N, Nakada H, Yamada A, Yamauchi K, Abe F, Nagasawa T: Supplementation of protein-free diet with whey protein hydrolysates prevents skeletal muscle mass loss in rats.Journal of Nutrition and Intermediary Metabolism. (2016)4(10): 1-5.

8. Kahokehr A, Sammour T, Soop M and Hill AG: Intraperitoneal local anaesthetic in abdominal surgery - a systematic review. ANZ J Surg. (2011) 81(4): 237-245.

9. Shin J, Seol I and Son C: Interpretation of Animal and Human Equivalent Dose for Drug Development. The Journal of Korean Oriental Medicine. (2010)31(3):1-7.

10. Landi F, Calvani R, Tosato M, Martone A, Ortolani E, Savera G, D'Angelo E, Sisto A and Marzetti E: Protein Intake and Muscle Health in Old Age: From Biological Plausibility to Clinical Evidence. Nutrients. (2016) 8(5):295-322.

11. Burton L and Sumukadas D: Optimal management of sarcopenia. Clinical Interventions in Aging. (2010)5(1):217-228.

12. Marzuca-Nassr G, Vitzel K, De Sousa L, Murata G, Crsma A, Junior C, Abreu P, Torres P, Mancini-Filho J, Hirabara S, Newsholme P and Curi R: Effects of high EPA and high DHA fish oils changes in signaling associated with protein metabolism induced by hind limb suspension in rats. Physiological Reports. (2016) 4(10):1-21.

13. Alway S, Bennett B, Wilson J, Sperringer J, Mohamed J, Edens N and Pereira S: Green tea extract attenuates muscle loss and improves muscle function during disuse, but fails to improve muscle recovery following unloading in aged rats. J Appl Physiol. (2014)118(10): 319-330.

14. Shrivastav $T$ and Kanaujia P: Direct radioimmunoassay for the measurement of serum testosterone using $3 \mathrm{H}$ as label. J Immunoassay Immunochem. (2007)28(2):127-136.

15. Camerino G, Desaphy J, Bellis M, Capogrosso
R, Cozolli A, Dinardo M, Caloiero R, Musaraj K, Fonzino A, Conte E, Jagerschmidt C, Namour F, Liantonio A, De Luca A, Camerino D and Pierno S: Effects of Nandrolone in the counteraction of skeletal muscle atrophy in a mouse model of muscle disuse: Molecular Biology and Functional Evaluation. PLOS ONE. (2015)10(6):1-24.

16. Kuru K: Optimization and enhancement of H\&E stained microscopical images by applying bilinear interpolation method on lab color mode. Theoretical Biology and Medical Modelling. (2014)11(1):9-18.

17. Young B, O'Dowd G and Woodford Ph: Muscle tissue In: Wheater's Functional Histology. A Text and Coloured Atlas. Sixth ed. Churchill Livingstone Elsevier. USA. (2014):101-121.

18. Suvarna K, Layton $\mathrm{C}$ and Bancroft J: Theory and Practice of Histological Techniques. Seventh ed. Churchill living-stone of el sevier, Philadelphia, USA. (2013): 173-214.

19. Meadows E, Cho J, Flynn J and Klein W: Myogenin regulates a distinct genetic program in adult muscle stem cells. Dev Biol.(2008) 322(2):406-414.

20. Emsley R, Dunn G and White IR: Mediation and moderation of treatment effects in randomized controlled trials of complex intervention. State Methods Med. Res. (2010)19:237-270.

21. Magne H, Savary-Auzeloux I, Rémond D and Dardevet D: Nutritional strategies to counteract muscle atrophy caused by disuse and to improve recovery. Nutr Res Rev. (2013)26(2):149-165.

22. Takagi M, Uchida T, Takatsu E, Kishimoto H, Ida K, Ishida Y, Ono-Ohmachi A, Morita Y, Kato K, Ochi A, Ohno-Maita A, Oarada M, Abe T, TeshimaKondo S, Nakao R, Hirasaka K and Takeshi N: Distinct Effects of Dietary Whey Peptide and Soy Protein on Denervation Mediated Muscle Atrophy. J Nutr Food Sci. (2016) 1(1002): 1-6.

23. Basualto-Alarcón $C$, Maass R, Jaimovich $E$ and Estrada M: Anabolic/Androgenic Steroids in Skeletal Muscle and Cardiovascular Diseases, Hot Topics in Endocrine and Endocrine-Related Diseases IntechOpen. (2013)10(2):237-267.

24. Chen Y, Zajac J and MacLean H: Androgen regulation of satellite cell function. J Endocrinol. (2005) 186(1):21-31.

25. Sheffield-Moore M, Dillon E, Casperson S, Gilkison C, Paddon-Jones D, Durham W, Grady J and Urban R: A randomized pilot study of monthly cycled testosterone replacement or continuous 
testosterone replacement versus placebo in older men. J ClinEndocrinolMetab. (2011)96(11):18311837.

26. Ito $\mathrm{K}$ and Suda $\mathrm{T}$ : Metabolic requirements for the maintenance of self-renewing stem cells. Nat Rev Mol Cell Biol. (2014)15(4): 243-256.

27. Bodine $\mathrm{S}$ : Disuse induced muscle wasting. Int $\mathrm{J}$ Biochem Cell Biol. (2013) 45(10): 2200-2208.

28. Carraro U, Boncompagni S, Gobbo V, Rossini K, Zampieri S, Mosole S, Ravara B, Nori A, Stramare R, Ambrosio F, Piccione F, Masiero S, Vindigni V, Gargiulo P, Protasi F, Kern H, Pond A and Marcante A: Persistent muscle fiber regeneration in long term denervation. Past, present, future. Eur J Transl Myol-Basic Appl Myol. (2015) 25(2):77-92.

29. Bunn J: Preventing muscle atrophy by protein and amino acid supplementation. Sports Medicine and Doping Studies. (2012)2(3): 22-35.

30. Mazzotti A and Coletti D: The Need for a Consensus on the Locution "Central Nuclei" in Striated Muscle Myopathies. Front Physiol. (2016)7: 577-583.

31. Dibble $\mathrm{C}$ and Manning B: Signal integration by mTORC1 coordinates nutrient input with biosynthetic output. Nat Cell Biol. (2013) 15(6): 555-564.

32. Simionescu A and Pavlath G: Molecular mechanisms of myoblast fusion across species. AdvExp Med Biol.(2010)713:113-135.
33. Brooks $\mathrm{N}$ and Myburgh K: Skeletal muscle wasting with disuse atrophy is multi-dimensional: the response and interaction of myonuclei, satellite cells and signaling pathways. Frontiers in Physiology.(2014)99(5): 1-14.

34. Fitts R, Riley D and Widrick J: Physiology of a microgravity environment invited review: Microgravity and Skeletal muscle. J appl. (2000)89(2): 823-831.

35. Tieland M, Trouwborst I and Clark B: Skeletal muscle performance and ageing. Journal of Cachexia, Sarcopenia and Muscle. (2018) 9: 3-19.

36. Ustunel I, Akkoyunlu G and Demir R: The effect of testosterone on gastrocnemius muscle fibres in growing and adult male and female rats: A histochemical, morphometric and ultrastructural study.Anat. Histol. Embryol. (2003)32 (2): 70-79.

37. Cribb P, Williams A, Stathis C, Carey M and Hayes A: Effects of whey isolate, creatine, and resistance training on muscle hypertrophy. Med Sci Sports Exerc. (2007) 39(2):298-307.

38. SnijdersT, Nederveen J, McKay B, Joanisse S, Verdijk L, Van Loon L and Parise G: Satellite cells in human skeletal muscle plasticity. Front Physiol. (2015) 21(6):283-292.

39. De Rooy C, Grossmann M, Zajac J and Cheung A: Targeting muscle signaling pathways to minimize adverse effects of androgen deprivation. Endocr Relat Cancer. (2016)23(1):15-26. 
الملخص العربى

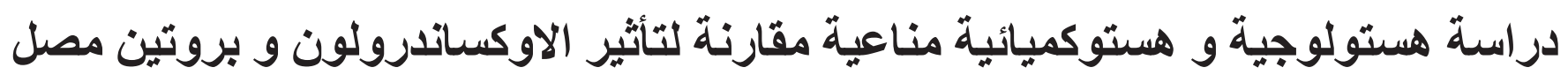

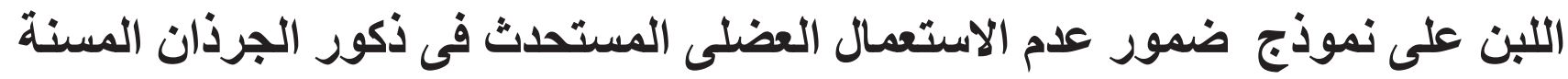

\section{سميحة على مرتضى، رحمة كمال الاين ابو النور، أمل الهام فارس، دينا \\ هثام محمد، قسم الهستولوجيا، كلية الطب، جامعة القاهرة}

الخلفية و الهلف من العمل: غالبًا ما ترتبط فترات توقف الحركة بالأمر اض و /أو الثنيخوخة. هذه الفترات من ضمور عدم استعمال العضلات يمكن أن تزيد من سوء الحالة المرضية أو ضعف المسنين. ممارسة الرياضة، أفضل طريقة لاستعادة كتلة العضلات ، لا يمكن تطيقها دائما. تختلف الاستر اتيجيات العلاجية لتخفيف هز ال العضلات وتحسين وظيفة العضلات في الفعالية.تهذف هذا الدر اسة لمقارنة التنأثير العلاجي للاوكساندرولون مقابل بروتين مصل اللبن على التى ضمور العضلات المستحدث عن طريق عدم الاستعمال في ذكور الجرذان المسنة ذات مستوى هرمون تستوستيرون منخفض وحركة محدودة. المواد والطرق: شملت الدراسة أربعة و عشرون من ذكور الجرذان البيضاء المسنة، 6 جرذان للمجموعة الضابطة (المجموعة الأولى). تم إخضاع ثمانية عشر جرذا لتعليق أطر افهم الخلفية لدة أسبو عين ، ثم تم تقسيمهم إلى: 6 جرذان

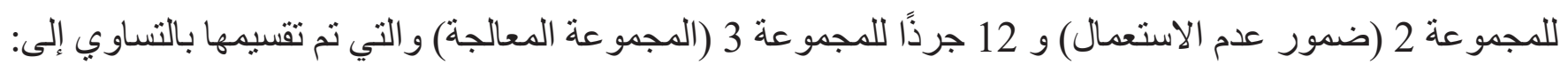
المجموعة 3أ (المعالجة بالأوكساندرولون) و 3ب (المعالجة ببروتين مصل اللبن) حيث تم اعطاء الأوكساندرولون 1,23مجم/كجم وبروتين مصل اللبن 9,25جم/كجم عن طريق الفم يوميا لددة 4 أسابيع. تمت التضحية بالفئران بعد 6 أسابيع. تم قياس وزن عضلة الساق ومحتوى البروتين الكلي. صبغت عينات العضلات بصبغة الهيماتوكسيلين و الإيوسين ، صبغة بيرايوديك شيف الحامضى، و الصبغ الهستوكيميائى المناعى ضد الميوجنين. تم أخذ القياسات المورفومترية لعدد و مساحة المقطع العرضى للنوع الأول و النوع الثاني من الألياف و عدد الخلايا الإيجابية للميوجنين وتحليلها إحصائياً. النتائج: أظهرت المجمو عة الثنانية ألياف عضلية ضامرة و زيادة ملحوظة في الألياف من النوع الثاني مقارنة بالمجموعة الضابطة. أظهرت المجمو عة الفرعية 3أ ألياف عضلية ذات قطر كبير. لوحظ وجود العديد من الأنوية الفاتحة الدائرية بين الألياف العضلية. زيادة بالغة في الألياف من النوع الاول و في عدد الخلايا الإيجابية للميوجنين المناعي مقارنة مع المجمو عة الضابطة و المجمو عة الفرعية 3ب. الاستنتاج: أظهرت المجموعات الفر عبة المعالجة بالأوكساندرولون و بروتينات مصل اللبن تحسين كتلة العضلات،

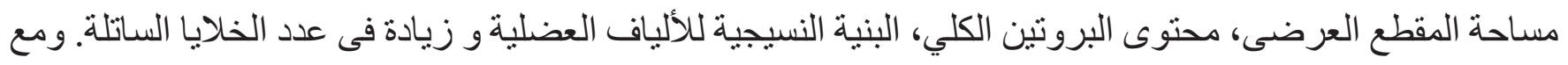

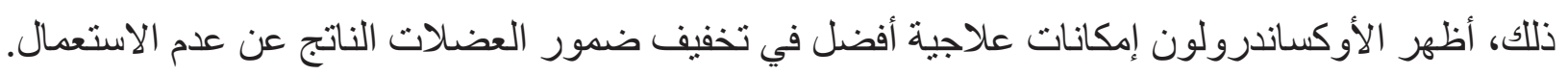

